Eur. J. Clin. Chem. Clin. Biochem.

Vol. 31, 1993, pp. $701-706$

(C) 1993 Walter de Gruyter \& Co. Berlin - New York

\title{
Comparison of the Automated Random Access Immunoassay Analysers, ACS-180 (Ciba Corning) and AIA-1200 (Tosoh)
}

\author{
By G. M. P. J. Costongs and P. C.W. Janson \\ Dept. Clinical Chemistry, Maaslandziekenhuis, Sittard, The Netherlands
}

(Received November 16, 1992/June 22, 1993)

\begin{abstract}
Summary: Two random access immunoassay analysers, the ACS-180 (Ciba Corning) and the AIA-1200 (Tosoh Corp.) were compared with respect to performance and user-friendliness. Precision studies revealed an almost equal intra-assay variation coefficient, but day-to-day reproducibility was better on the AIA-1200. Recovery of dilution series of tumour markers was too high with the ACS-180. Both systems were free from carry-over effects, on account of the extra wash step in the ACS-180 (for thyrotropin, carcinoembryonic antigen and human chorionic gonadotropin) and the separate pipetting tip in the AIA-1200. Reagent stability is better in the AIA-1200 than in the ACS-180. The AIA-1200 is more user-friendly and produces a higher throughput than the ACS-180 in daily routine operation (92 results/hour vs. 78 results/hour).
\end{abstract}

\section{Introduction}

Automation of patient blood analysis is becoming more and more inevitable. Automation is not only required in routine clinical chemistry and haematology, but can also conver great benefit in the immunoassay laboratory (1). Because of their around-theclock availability, automated systems should be easy to handle and as flexible as possible to enable all laboratory personnel to work with them at all times. Availability of random access together with the use of primary tubes, using bar code labelling and connection with the administrative host computer, plays a crucial role in the automation process.

In our view, there are at present (May 1993) two important random access automated immunoassay analysers available in the Netherlands, the ACS-180 (Ciba Corning Diagnostics, Mefield, MA, USA) and the AIA-1200 (Tosoh Corporation, Tokyo, Japan, represented in Europe by Eurogenetics, Tessenderlo, Belgium). Because of the need for immunoassay automation in our laboratory, and in the context of the above-mentioned requirements, we decided to evaluate these two analysers. For this purpose we monitored precision, recovery, and the correlation between both systems and the routine method.
The user-friendliness, and ease-of-use were evaluated as well as the way in which both instruments behaved during three days of simulated heavy routine activity, without jeopardizing the quality of the results produced.

\section{Materials and Methods}

\section{Apparatus}

\section{ACS -180}

The instrument is a bench-top system $(2,3)$. Reagents and samples are placed in disposable plastic cuvettes, which are automatically loaded onto a linear process track. The reaction takes place at $37^{\circ} \mathrm{C}$. Samples are placed in a 60-position tray for loading patient samples in primary tubes, calibrators, controls and diluents. Close to the tray is a laser barcode reader and digital diluter. A second tray provides a carrier for 26 reagent bottles, sufficient for up to 13 different analytes at one time. When a cuvette reaches the end of the 7.5 minute incubation time, separation and washing of the solid phase, consisting of magnetic particles, is carried out. The particles are then resuspended in $300 \mu \mathrm{l}$ of flash reagent 1 , containing $5 \mathrm{~g} / 1$ hydrogen peroxide in $0.1 \mathrm{~mol} / \mathrm{l}$ nitric acid. Flash reagent 2 , containing $0.25 \mathrm{~mol} / \mathrm{l}$ sodium hydroxide is then injected into the cuvette, which results in oxidation of the acridinium ester tracer and emission of photons $(430 \mathrm{~nm})$. The end-point intensity of the emission is measured over a 5 second interval. The counts are used to calculate analyte concentration in the sample using a stored master curve. 


\section{AIA-1200}

The instrument is a floor-standing model $(4,5,6)$. Reagents and samples react in disposable plastic cups, the AlA-Packs, which contain antibody-coated magnetic beads and lyophilized alkaline phosphatase')-conjugated tracer. Up to 80 bar codelabelled patient samples, calibrators and controls can be loaded into separate plastic sample racks (in series of 10). Each sample rack passes along a laser bar code reader, then automatically continues into the sampling area. Twenty one different analytes may be kept on board simultaneously, in trays of 20 AIAPacks. Once the assay process starts, the AIA-1200 arranges the necessary AlA-Packs from a reagent inventory drawer in intermediate transport blocks, which are then also brought to the pipetting area. After pipetting, the incubation period of 40 minutes at $37^{\circ} \mathrm{C}$ is started. A moving magnetic field inside the incubator shakes the magnetic beads inside the AIA-Packs, homogenizing the reaction mixture. After the incubation, the test cup contents are thoroughly washed. Preheated substrate (220 $\mu \mathrm{l}$, 4-methyl-umbelliferyl phosphate) is injected after the final wash and the reagent cup which also acts as a cuvette is immediately placed under the fluorescence detector. The fluorescence is measured kinetically and the fluorescence rate is used to calculate the analyte concentration in the sample, using a stored calibration curve.

\section{Reagents for comparison of methods}

For the correlation with other methods about 100 samples from out-patients and hospitalised patients between 18 and 80 years old (50\% males, $50 \%$ females) were analysed with the routine method and with the ACS-180 and AIA-1200. The routine methods included the Tosoh AIA-600 for thyroxine, human chorionic gonadotropin, carcinoembryonic antigen, prostatespecific antigen and ferritin; assays for lutropin, follitropin, prolactin, thyrotropin and triiodothyronine were made on the Amerlite system (Amersham, Aylesbury, UK).

All sera used in this study were samples normally sent to the laboratory of the hospital from both clinical patients and outpatients. Regression coefficients were calculated according to the Deming orthogonal regression $(7,8)$.

\section{Precision}

To assess the intra-run precision, samples of pooled patient sera were assayed thirty times. It should be noted that pool 1 was an albumin-globulin solution, spiked with pooled human serum containing a high concentration of thyrotropin. Inter-run dayto-day precision was assessed using the same pooled patient sera, frozen in small aliquots at $-20^{\circ} \mathrm{C}$, and commercial control sera (Lyphochek Immunoassay Control, BioRad, Mountain View, California, USA). Assays were carried out at regular intervals during at least one calibration/recalibration period of 30 days. Precision is expressed as standard deviation and coefficient of variation (9).

\section{Dilution}

Patient sera were diluted with dilution medium provided by Ciba Corning and Tosoh Corporation, and with human sera containing very low analyte concentrations. All dilutions were made from the primary tube.

\section{') Enzyme}

Alkaline Phosphatase (EC 3.1.3.1)

\section{Results and Discussion}

\section{Precision}

The intra-run precision (tab. 1), varies from 2 to $9 \%$ for the ACS-180 and from 2 to $7 \%$ for the AIA- 1200 . However, an intra-run precision of $18.4 \%$ was found for carcinoembryonic antigen on the ACS-180, and values of $22.4 \%$ and $16.6 \%$, respectively, were found for triiodothyronine and thyrotropin on the AIA1200.

The inter-run (day-to-day) precision (tab. 2) varies from 4 to $13 \%$ for the ACS-180 and from 2.5 to $7 \%$ for the AIA-1200. Larger values were found, however, for low concentration of lutropin and triiodothyronine on the ACS-180, and for low concentrations of thyrotropin, triiodothyronine and lutropin on the AIA-1200.

As mentioned above, pool 1 was an albumin-globulin solution, spiked with pooled human serum containing a high concentration of thyrotropin. Occurrence of a matrix effect can therefore not be excluded in the original pool 1 . To check this possibility, two $100 \%$ human serum samples with a thyrotropin concentration of 0.16 and $0.21 \mathrm{mIU} / \mathrm{l}$, were assayed 5 times during 5 days. Analytical variations of $6 \%$ and $8 \%$ (intra-assay), and 11.4 and $9.7 \%$ (inter-assay), respectively, were found with the AIA-1200, which corresponds with the findings of Chan \& Thornton (5).

The intra-assay results are shown in table 1 . It can be seen that the AIA-1200 and ACS-180 are comparable for almost all quantities, except triiodothyronine (ACS-180 better), lutropin (ACS-180 better in the low range), follitropin (AIA-1200 better in the low range), human chorionic gonadotropin and carcinoembryonic antigen (AIA-1200 better). The AIA-1200 also gives better inter-assay results for thyrotropin, follitropin, human chorionic gonadotropin, carcinoembryonic antigen, prostate-specific antigen and ferritin. The ACS-180 only gives better results for lutropin (tab. 2).

\section{Dilution curves}

Ciba Corning provides 2 types of diluent for each analyte, whereas Tosoh provides one diluent for each analyte. When sera are diluted with these diluents, a satisfactory result is obtained for the AIA $=1200$ in most cases, except for lutropin, and thyrotropin in the low range where a variable recovery between 50 and $130 \%$ is observed. The ACS- 180 gives a higher recovery (above 120\%) for all tests except follitropin, ferritin, triiodothyronine, prolactin and human chorionic gonadotropin. 
Tab. 1. Intra-run variations for thyroid hormones, fertility hormones and tumour markers measured in three different human serum pools on the AIA-1200 and the ACS-180.

1a. Thyroid

\begin{tabular}{|c|c|c|c|c|c|c|c|c|}
\hline & & ACS-180 & AIA-1200 & ACS-180 & AIA-1200 & ACS-180 & AIA-1200 & unit \\
\hline Analyte & & Pool I & & Pool II & & Pool III & & \\
\hline Total $T_{4}$ & $\begin{array}{l}\bar{x} \\
S D \\
C V\end{array}$ & $\begin{array}{c}67.6 \\
2.53 \\
3.7\end{array}$ & $\begin{array}{c}64.1 \\
2.43 \\
3.8\end{array}$ & $\begin{array}{c}105.4 \\
3.84 \\
3.6\end{array}$ & $\begin{array}{c}99.8 \\
3.60 \\
3.6\end{array}$ & $\begin{array}{c}238.1 \\
8.85 \\
3.7\end{array}$ & $\begin{array}{c}223.6 \\
9.03 \\
4.0\end{array}$ & $\begin{array}{l}\mathrm{nmol} / \mathrm{l} \\
\mathrm{nmol} / \mathrm{l} \\
\%\end{array}$ \\
\hline Thyrotropin & $\begin{array}{l}\bar{x} \\
\text { SD } \\
C V\end{array}$ & $\begin{array}{l}0.20 \\
0.014 \\
6.8\end{array}$ & $\begin{array}{l}0.18 \\
0.029 \\
16.6\end{array}$ & $\begin{array}{l}9.45 \\
0.290 \\
3.1\end{array}$ & $\begin{array}{l}10.16 \\
0.290 \\
2.8\end{array}$ & $\begin{array}{c}107.20 \\
6.000 \\
5.6\end{array}$ & $\begin{array}{c}107.00 \\
4.030 \\
3.8\end{array}$ & $\begin{array}{l}\mathrm{mU} / 1 \\
\mathrm{mU} / \mathrm{l} \\
\%\end{array}$ \\
\hline Triiodothyronine & $\begin{array}{l}\bar{x} \\
S D \\
C V\end{array}$ & $\begin{array}{l}0.90 \\
0.078 \\
8.6\end{array}$ & $\begin{array}{l}0.39 \\
0.087 \\
22.4\end{array}$ & $\begin{array}{l}1.78 \\
0.070 \\
3.9\end{array}$ & $\begin{array}{l}1.67 \\
0.110 \\
6.8\end{array}$ & $\begin{array}{l}6.22 \\
0.180 \\
2.8\end{array}$ & $\begin{array}{l}5.34 \\
0.210 \\
3.9\end{array}$ & $\begin{array}{l}\mathrm{nmol} / \mathrm{l} \\
\mathrm{nmol} / \mathrm{l} \\
\%\end{array}$ \\
\hline
\end{tabular}

1b. Fertility

\begin{tabular}{|c|c|c|c|c|c|c|c|c|}
\hline & & ACS-180 & AlA-1200 & ACS-180 & AIA-1200 & ACS-180 & AIA-1200 & unit \\
\hline Analyte & & Pool I & & Pool II & & Pool III & & \\
\hline Lutropin & $\begin{array}{l}\overline{\mathbf{x}} \\
\text { SD } \\
C V\end{array}$ & $\begin{array}{l}2.7 \\
0.12 \\
4.4\end{array}$ & $\begin{array}{l}1.5^{*} \\
-\end{array}$ & $\begin{array}{c}20.3 \\
0.53 \\
2.6\end{array}$ & $\begin{array}{c}10.4 \\
0.60 \\
5.8\end{array}$ & $\begin{array}{c}48.6 \\
1.76 \\
3.6\end{array}$ & $\begin{array}{c}39.1 \\
1.20 \\
3.1\end{array}$ & $\begin{array}{l}U / 1 \\
U / 1 \\
\%\end{array}$ \\
\hline Follitropin & $\begin{array}{l}\overline{\mathbf{x}} \\
\mathrm{SD} \\
\mathrm{CV}\end{array}$ & $\begin{array}{l}3.2 \\
0.27 \\
8.6\end{array}$ & $\begin{array}{l}4.4 \\
0.13 \\
3.1\end{array}$ & $\begin{array}{c}12.1 \\
0.60 \\
5.0\end{array}$ & $\begin{array}{c}16.3 \\
0.51 \\
3.2\end{array}$ & $\begin{array}{c}62.4 \\
2.95 \\
4.7\end{array}$ & $\begin{array}{c}87.6 \\
2.23 \\
2.6\end{array}$ & $\begin{array}{l}U / 1 \\
U / 1 \\
\%\end{array}$ \\
\hline Prolactin & $\begin{array}{l}\overline{\mathbf{x}} \\
\text { SD } \\
C V\end{array}$ & $\begin{array}{l}0.14 \\
0.006 \\
4.0\end{array}$ & $\begin{array}{l}0.16 \\
0.007 \\
4.1\end{array}$ & $\begin{array}{l}0.57 \\
0.014 \\
2.4\end{array}$ & $\begin{array}{l}0.63 \\
0.022 \\
3.6\end{array}$ & $\begin{array}{l}2.99 \\
0.142 \\
4.7\end{array}$ & $\begin{array}{l}3.75 \\
0.150 \\
4.0\end{array}$ & $\begin{array}{l}U / 1 \\
U / 1 \\
\%\end{array}$ \\
\hline $\begin{array}{l}\text { Human chorionic } \\
\text { gonadotropin }\end{array}$ & $\begin{array}{l}\overline{\mathbf{x}} \\
\mathrm{SD} \\
\mathrm{CV}\end{array}$ & $\begin{array}{l}12.8 \\
0.90 \\
7.0\end{array}$ & $\begin{array}{c}13.2 \\
0.41 \\
3.1\end{array}$ & $\begin{array}{c}50.9 \\
2.01 \\
4.0\end{array}$ & $\begin{array}{l}57.1 \\
1.28 \\
2.2\end{array}$ & $\begin{array}{c}244.1 \\
10.46 \\
4.3\end{array}$ & $\begin{array}{c}286.9 \\
6.22 \\
2.2\end{array}$ & $\begin{array}{l}U / 1 \\
U / 1 \\
\%\end{array}$ \\
\hline
\end{tabular}

* Detection limit 2 U/1 (AIA-1200)

1c. Tumour Markers

\begin{tabular}{|c|c|c|c|c|c|c|c|c|}
\hline & & ACS-180 & AIA-1200 & ACS-180 & AIA-1200 & ACS-180 & AIA-1200 & unit \\
\hline Analyte & & Pool I & & Pool II & & Pool III & & \\
\hline Carcinoembryonic antigen & $\begin{array}{l}\bar{x} \\
\text { SD } \\
C V\end{array}$ & $\begin{array}{c}1.2 \\
0.22 \\
18.4\end{array}$ & $\begin{array}{l}2.3 \\
0.11 \\
4.8\end{array}$ & $\begin{array}{l}4.6 \\
0.24 \\
5.2\end{array}$ & $\begin{array}{l}7.7 \\
0.27 \\
3.5\end{array}$ & $\begin{array}{c}46.2 \\
1.74 \\
3.8\end{array}$ & $\begin{array}{l}70.5 \\
2.01 \\
2.9\end{array}$ & $\begin{array}{l}\mu \mathrm{g} / 1 \\
\mu \mathrm{g} / 1 \\
\%\end{array}$ \\
\hline Prostate-specific antigen & $\begin{array}{l}\bar{x} \\
\text { SD } \\
C V\end{array}$ & $\begin{array}{l}3.3 \\
0.15 \\
4.6\end{array}$ & $\begin{array}{l}2.5 \\
0.08 \\
3.1\end{array}$ & $\begin{array}{c}23.8 \\
0.59 \\
2.5\end{array}$ & $\begin{array}{c}14.5 \\
0.38 \\
2.6\end{array}$ & $\begin{array}{c}67.6 \\
2.19 \\
3.2\end{array}$ & $\begin{array}{c}46.2 \\
1.48 \\
3.2\end{array}$ & $\begin{array}{l}\mu \mathrm{g} / 1 \\
\mu \mathrm{g} / 1 \\
\%\end{array}$ \\
\hline Ferritin & $\begin{array}{l}\overline{\mathbf{x}} \\
\text { SD } \\
\text { CV }\end{array}$ & $\begin{array}{c}27.2 \\
0.53 \\
1.9\end{array}$ & $\begin{array}{l}23.8 \\
0.84 \\
3.5\end{array}$ & $\begin{array}{c}86.5 \\
1.88 \\
2.2\end{array}$ & $\begin{array}{c}79.8 \\
2.71 \\
3.4\end{array}$ & $\begin{array}{c}591.4 \\
18.77 \\
3.2\end{array}$ & $\begin{array}{c}676.1 \\
21.36 \\
3.2\end{array}$ & $\begin{array}{l}\mu \mathrm{g} / 1 \\
\mu \mathrm{g} / \mathrm{l} \\
\%\end{array}$ \\
\hline
\end{tabular}

When home-made dilution serum is used for both systems, results are mostly acceptable. The ACS 180 has an elevated recovery for prostate-specific antigen, carcinoembryonic antigen and thyrotropin in the high range $(>120 \%)$. The AIA -1200 has a recovery below $90 \%$ for ferritin, follitropin, triiodothyronine, and thyrotropin (low range).
Results from the dilution of a low thyrotropin sample on the AIA-1200 are poor. However, when 20 samples, giving $<0.03 \mathrm{mIU} / 1$ on the Amerlite system, were assayed on the AIA-1200, 18 of them gave a result of $<0.05 \mathrm{mIU} / 1$ and 2 gave a result of 0.05 $\mathrm{mIU} / \mathrm{l}$. This is in agreement with the observations of Chan \& Thornton (5) who found a sensitivity of 0.04 
Tab. 2. Inter-run (day-to-day) variations for thyroid hormones, fertility hormones and tumour markers measured in three different human serum pools or with Bio-Rad Lyphocheck control serum on the AIA-1200 and the ACS-180.

2a. Thyroid

\begin{tabular}{|c|c|c|c|c|c|c|c|c|}
\hline & & ACS-180 & AIA-1200 & ACS-180 & AIA-1200 & ACS-180' & AIA-1200 & unit \\
\hline Analyte & & Pool I & & Pool II & & Pool III & & \\
\hline Total $\mathrm{T}_{4}$ & $\begin{array}{l}\bar{x} \\
\text { SD } \\
C V\end{array}$ & $\begin{array}{c}52.6 \\
4.63 \\
8.8\end{array}$ & $\begin{array}{c}48.7 \\
2.76 \\
5.8\end{array}$ & $\begin{array}{c}105.9 \\
5.61 \\
5.3\end{array}$ & $\begin{array}{r}94.8 \\
5.4 \\
5.7\end{array}$ & $\begin{array}{c}214.0 \\
10.81 \\
5.1\end{array}$ & $\begin{array}{c}180.2 \\
5.56 \\
3.1\end{array}$ & $\begin{array}{l}\mathrm{nmol} / \mathrm{l} \\
\mathrm{nmol} / \mathrm{l} \\
\%\end{array}$ \\
\hline Thyrotropin & $\begin{array}{l}\overline{\mathbf{x}} \\
\mathrm{SD} \\
\mathrm{CV}\end{array}$ & $\begin{array}{l}0.19 \\
0.025 \\
13.3\end{array}$ & $\begin{array}{l}0.10 \\
0.032 \\
33.2\end{array}$ & $\begin{array}{c}1.14 \\
0.141 \\
12.3\end{array}$ & $\begin{array}{l}1.59 \\
0.063 \\
4.0\end{array}$ & $\begin{array}{l}3.38 \\
0.343 \\
10.2\end{array}$ & $\begin{array}{l}4.07 \\
0.102 \\
2.5\end{array}$ & $\begin{array}{l}\mathrm{mU} / 1 \\
\mathrm{mU} / 1 \\
\%\end{array}$ \\
\hline Thyrotropin* & $\begin{array}{l}\bar{x} \\
S D \\
C V\end{array}$ & & & & & $\begin{array}{c}25.94 \\
2.700 \\
10.4\end{array}$ & $\begin{array}{c}28.59 \\
0.796 \\
2.8\end{array}$ & \\
\hline Triiodothyronine & $\begin{array}{l}\bar{x} \\
\text { SD } \\
C V\end{array}$ & $\begin{array}{c}0.30 \\
0.10 \\
32.0\end{array}$ & $\begin{array}{l}0.51 \\
0.05 \\
10.3\end{array}$ & $\begin{array}{l}1.58 \\
0.11 \\
6.8\end{array}$ & $\begin{array}{l}1.60 \\
0.11 \\
7.2\end{array}$ & $\begin{array}{l}5.63 \\
0.37 \\
6.6\end{array}$ & $\begin{array}{l}6.05 \\
0.20 \\
3.4\end{array}$ & $\begin{array}{l}\mathrm{nmol} / \mathrm{l} \\
\mathrm{nmol} / \mathrm{l} \\
\%\end{array}$ \\
\hline
\end{tabular}

* Lyphochek level III

2b. Fertility

\begin{tabular}{|c|c|c|c|c|c|c|c|c|}
\hline & & ACS-180 & AIA-1200 & ACS-180 & AIA-1200 & ACS-180 & AIA-1200 & unit \\
\hline Analyte & & Pool I & & Pool II & & Pool III & & \\
\hline Lutropin & $\begin{array}{l}\bar{x} \\
S D \\
C V\end{array}$ & $\begin{array}{c}1.3 \\
0.25 \\
18.7\end{array}$ & $\begin{array}{l}0.9^{*} \\
- \\
-\end{array}$ & $\begin{array}{l}6.0 \\
0.36 \\
6.0\end{array}$ & $\begin{array}{l}3.2 \\
0.38 \\
11.9\end{array}$ & $\begin{array}{c}14.6 \\
0.61 \\
4.2\end{array}$ & $\begin{array}{c}10.8 \\
0.59 \\
5.5\end{array}$ & $\begin{array}{l}U / 1 \\
U / 1 \\
\%\end{array}$ \\
\hline Follitropin & $\begin{array}{l}\bar{x} \\
S D \\
C V\end{array}$ & $\begin{array}{l}5.1 \\
0.29 \\
5.7\end{array}$ & $\begin{array}{l}7.1 \\
0.21 \\
3.0\end{array}$ & $\begin{array}{c}13.2 \\
0.59 \\
4.5\end{array}$ & $\begin{array}{c}14.0 \\
0.36 \\
2.6\end{array}$ & $\begin{array}{c}44.1 \\
2.85 \\
6.5\end{array}$ & $\begin{array}{c}37.7 \\
1.06 \\
2.8\end{array}$ & $\begin{array}{l}\mathrm{U} / 1 \\
\mathrm{U} / 1 \\
\%\end{array}$ \\
\hline Prolactin & $\begin{array}{l}\bar{x} \\
S D \\
C V\end{array}$ & $\begin{array}{l}0.26 \\
0.020 \\
7.8\end{array}$ & $\begin{array}{l}0.27 \\
0.018 \\
6.8\end{array}$ & $\begin{array}{l}0.46 \\
0.031 \\
6.8\end{array}$ & $\begin{array}{l}0.53 \\
0.037 \\
7.0\end{array}$ & $\begin{array}{l}1.06 \\
0.067 \\
6.3\end{array}$ & $\begin{array}{l}1.19 \\
0.064 \\
5.4\end{array}$ & $\begin{array}{l}U / 1 \\
U / 1 \\
\%\end{array}$ \\
\hline $\begin{array}{l}\text { Human chorionic } \\
\text { gonadotropin }\end{array}$ & $\begin{array}{l}\overline{\mathbf{x}} \\
\mathrm{SD} \\
\mathrm{CV}\end{array}$ & $\begin{array}{c}13.0 \\
1.73 \\
13.4\end{array}$ & $\begin{array}{l}6.1 \\
0.22 \\
3.6\end{array}$ & $\begin{array}{c}17.6 \\
1.07 \\
6.1\end{array}$ & $\begin{array}{c}10.1 \\
0.24 \\
2.4\end{array}$ & $\begin{array}{c}99.0 \\
8.50 \\
8.6\end{array}$ & $\begin{array}{c}52.9 \\
1.77 \\
3.3\end{array}$ & $\begin{array}{l}U / 1 \\
U / 1 \\
\%\end{array}$ \\
\hline
\end{tabular}

* Detection limit 2 U/1 (AIA-1200)

2c. Tumour Markers

\begin{tabular}{|c|c|c|c|c|c|c|c|c|}
\hline & & ACS-180 & AIA-1200 & ACS-180 & AIA-1200 & ACS-180 & AIA-1200 & unit \\
\hline Analyte & & Pool I & & Pool II & & Pool III & . & \\
\hline Carcinoembryonic antigen & $\begin{array}{l}\bar{x} \\
\text { SD } \\
C V\end{array}$ & $\begin{array}{l}4.1 \\
0.37 \\
9.0\end{array}$ & $\begin{array}{l}2.8 \\
0.18 \\
6.3\end{array}$ & $\begin{array}{l}4.8 \\
0.32 \\
6.5\end{array}$ & $\begin{array}{l}8.1 \\
0.25 \\
3.1\end{array}$ & $\begin{array}{c}25.2 \\
1.14 \\
4.5\end{array}$ & $\begin{array}{c}38.0 \\
1.30 \\
3.4\end{array}$ & $\begin{array}{l}\mu g / 1 \\
\mu g / 1 \\
\%\end{array}$ \\
\hline Prostate-specific antigen & $\begin{array}{l}\bar{x} \\
\text { SD } \\
C V\end{array}$ & $\begin{array}{l}4.0 \\
0.34 \\
8.3\end{array}$ & $\begin{array}{l}1.6 \\
0.08 \\
4.8\end{array}$ & $\begin{array}{c}20.5 \\
1.35 \\
6.6\end{array}$ & $\begin{array}{l}6.9 \\
0.25 \\
3.6\end{array}$ & $\begin{array}{c}42.4 \\
2.80 \\
6.6\end{array}$ & $\begin{array}{c}14.8 \\
0.51 \\
3.4\end{array}$ & $\begin{array}{l}\mu \mathrm{g} / 1 \\
\mu \mathrm{g} / 1 \\
\%\end{array}$ \\
\hline Ferritin & $\begin{array}{l}\bar{x} \\
\text { SD } \\
C V\end{array}$ & $\begin{array}{c}38.1 \\
2.69 \\
7.1\end{array}$ & $\begin{array}{c}46.8 \\
2.05 \\
4.4\end{array}$ & $\begin{array}{c}120.5 \\
6.62 \\
5.6\end{array}$ & $\begin{array}{c}124.0 \\
4.58 \\
3.7\end{array}$ & $\begin{array}{c}283.7 \\
20.82 \\
7.3\end{array}$ & $\begin{array}{c}319.6 \\
12.52 \\
3.9\end{array}$ & $\begin{array}{l}\mu \mathrm{g} / \mathrm{l} \\
\mu \mathrm{g} / 1 \\
\%\end{array}$ \\
\hline
\end{tabular}


Tab. 3. Correlations between the ACS-180 and the AIA-1200, and the routine method respectively.

\begin{tabular}{|c|c|c|c|c|c|c|c|}
\hline \multirow[t]{2}{*}{ Analyte } & \multirow{2}{*}{$\begin{array}{l}\text { Routine } \\
\text { method }\end{array}$} & \multicolumn{3}{|c|}{ Versus ACS-180 } & \multicolumn{3}{|c|}{ Versus AIA-1200 } \\
\hline & & slope & intercept & $\mathbf{r}$ & slope & intercept & $\mathbf{r}$ \\
\hline Thyroxine & AIA-600 & 1.081 & 5.376 & 0.9658 & 0.960 & 2.100 & 0.9707 \\
\hline Triiodothyronine & Amerlite & 1.079 & -0.013 & 0.9845 & 1.050 & -0.577 & 0.9740 \\
\hline Thyrotropin & Amerlite & 1.322 & -0.022 & 0.9938 & 1.321 & 0.159 & 0.9927 \\
\hline Lutropin & Amerlite & 1.397 & -1.064 & 0.9666 & 1.159 & -1.621 & 0.9845 \\
\hline Follitropin & Amerlite & 1.053 & -1.570 & 0.9878 & 1.569 & -2.924 & 0.9967 \\
\hline Prolactin & Amerilite & 1.131 & -0.153 & 0.9890 & 1.098 & -0.163 & 0.9876 \\
\hline $\begin{array}{l}\text { Human chorionic } \\
\text { gonadotropin }\end{array}$ & AIA-600 & 1.040 & 9.993 & 0.9821 & 0.990 & 2.790 & 0.9972 \\
\hline Carcinoembryonic antigen & AIA-600 & 0.509 & 0.478 & 0.8907 & 0.959 & -0.046 & 0.9860 \\
\hline Prostate-specific antigen & AIA-600 & 1.454 & 2.728 & 0.9733 & 1.011 & 0.227 & 0.9951 \\
\hline Ferritin & AIA-600 & 1.099 & -9.435 & 0.9839 & 1.025 & -0.844 & 0.9961 \\
\hline
\end{tabular}

$\mathrm{mIU} / \mathrm{l}$, and of Inoue et al. (6) who reported a sensitivity between 0.04 and $0.07 \mathrm{mIU} / \mathrm{l}$.

\section{Correlations}

All correlations with the range, number of pairs (n), regression coefficients (slope, intercept), and the correlation coefficient $(r)$ are given in table 3.

Thyroxine: although the slope is close to unity and the correlation coefficient is good, the ACS-180 tends to give higher results.

Triiodothyronine: correlation and slope are identical for both methods. Although the slope is close to unity and the intercept is close to zero, an unacceptable correlation in the low range is observed for the AIA1200. This holds for the correlation AIA- 1200 vs. Amerlite as well as for the correlation AIA-1200 vs. ACS-180.

Thyrotropin: correlation is identical for both methods, and they both have a slope of about 1.3. A separate series of 70 samples with a concentration range from 0.03 to $0.4 \mathrm{mIU} / 1$ was assayed on the AIA-1200. Compared with the Amerlite method, a slope of 1.028 and an intercept of 0.04 was observed $(\mathrm{r}=0.8997)$.

Lutropin: the overall correlation is acceptable.

Follitropin: the overall correlation is good.

Human chorionic gonadotropin: both methods can be considered as equivalent.

Prolactin: both correlations are acceptable.

Carcinoembryonic antigen: the correlation of the ACS-180 is only $0: 89$, probably due to the high variation of this carcinoembryonic antigen method and to the bad recovery.

Prostate specific antigen: ACS-180 registers higher values than AIA-1200.
Ferritin: both methods can be considered as equivalent.

\section{User-friendly aspects and practicability}

\section{Reagent stability}

Reagents for the ACS-180 are packaged in 1,3 or 6 units of 50 test volumes. When stored at $2-8{ }^{\circ} \mathrm{C}$, they are stable for 4 months; at room temperature, we found them to be stable for only 40 hours.

The AIA-1200 reagents are delivered in 10 AIA-Pack trays containing 20 cups per tray. They are stable for 12 months at $2-8^{\circ} \mathrm{C}$; at room temperature we found them to be stable for at least 7 days.

Reagents for the AIA-1200 are significantly more stable than those for the ACS- 180 .

\section{Carry-over}

Carry-over is theoretically possible on the ACS- 180 because of the use of a fixed pipetting probe. To avoid carry-over, an extra wash step is introduced for some quantities such as thyrotropin, carcinoembryonic antigen and human chorionic gonadotropin. The reaction time is then increased from 7.5 to 8.5 minutes, and the rate of throughput is reduced. After an $\mathrm{NaOH}$ wash, we only observed $0.0004 \%$ carry-over for human chorionic gonadotropin.

Carry-over is impossible on the AIA-1200 because disposable pipette tips are used for each sample.

\section{Routine simulation}

Both instruments were compared continuously during a 4 week period. During three days a heavy routine activity was simulated. Ciba Corning claimed 180 results/hour, so we planned to verify this during a working day of 8 hours with 7 hours real operation, i. e. 7 times $180=1260$ tests. In practice we proceeded 
as follows. On the first day, three series of 100 patient sera were subsequently presented to each instrument. Four tests were performed on each patient serum. On the second day, four series of 75 samples were presented to each instrument. On the third day, six series of 50 samples were presented. This third day shows the closest correspondence with the real daily situation in our laboratory.

Neither instrument produced results at the theoretical rate (180 results/hour for the ACS-180, and 120 results/hour for the AIA-1200). The AIA-1200 came closest to the theoretical value with 92 results/hour. The ACS-180 was far behind with 78 results/hour. This lower production rate in the ACS-180 is mainly due to longer reaction times for thyrotropin, carcinoembryonic antigen and human chorionic gonadotropin (8.5 minutes instead of 7.5) and stoppage of the instrument caused by reagent shortage and time for refilling. This is due to the absence of a reagent inventory in the system. In the AIA-1200, reagent and sera may be added continuously and in time because of the active reagent inventory; refilling did not cause any delay. Moreover, all tests have a constant incubation time of 40 minutes.

The ACS-180 gives multiple (and almost always irrelevant) warnings on the screen, which is upsetting to the laboratory technician. On the other hand, the ACS-180 carries out dilutions of samples automatically.

\section{References}

1. Ricos, C. \& Arbos, M. A. (1990) Quality Goals for Hormone Testing. Ann. Clin. Biochem. 27, 353-358.

2. Dudley, R. F. (1991) The Ciba Corning ACS-180 Automated Immunoassay System. J. Clin. Immunoassay 14, 77-82.

3. O'Brien, J. F., Klee, G. G. \& Shellum, C. L. (1992) The Magic Lite System and Acridinium Ester-based Immunoassays. In: Immunoassay Automation - A Practical Guide (Chan, D. W., ed.) Academic Press, San Diego. pp. 221 242.

4. Loebel, J. E. (1991) Tosoh AIA-1200/AIA-600 Automated Immunoassay Analyzers. J. Clin. Immunoassay 14, 94-102.

5. Chan, D. W. \& Thornton, P. L. (1992) AIA-1200 Immunoassay System. In: Immunoassay Automation - A Practical Guide (Chan, D. W., ed.) Academic Press, San Diego. pp. $221-242$.

\section{Conclusions}

The analytical precision is in general higher on the AIA-1200 than on the ACS-180.

Carry-over is not possible in the AIA-1200, but can be avoided in the ACS- 180 by using an alternative procedure which causes a reduction of the result production rate.

The AIA-1200 is more user-friendly than the ACS180 , because it has continuous access for reagents and samples.

The AIA-1200 also has a higher throughput than the ACS-180: 92 compared with 78 tests/hour, when used in daily routine random access conditions.

The AIA-1200 has an active reagent inventory which was not present on the ACS-180 at the moment of our evaluation.

We conclude that the AIA-1200 corresponds better to the automation needs of a modern clinical laboratory, especially with respect to capacity, flexibility, user-friendliness and ease-of-use.

\section{Acknowledgement}

The authors wish to thank Ciba Corning and EurogeneticsTosoh for placing the instruments and the necessary reagents at their disposal. W. Hermans is thanked for skilful technical operation of the instruments.
6. Inoue, M., Hayashi, H., Suzuki, H. \& Nakamura, H. (1990) Magnetic micro-beads EIA by utilization of fully automated Random Access Enzyme Immunoassay Analyzer, AIA-1200. In: Automation and New Technology in the Clinical Laboratory (Okuda, K., ed.) Blackwell Scientific Publications. pp. $73-90$.

7. Cornbleet, P. J. \& Gochman, N. (1979) Incorrect Least Squares Regression Coefficients in Methods-Comparison Analysis. Clin. Chem. 25, 432.

8. Bookbinder, M. J. \& Panosian, K. J. (1987) Using the Coefficient of Correlation in Method-Comparison Studies. Clin. Chem. 33, 1170-1176.

9. Swinsow, D. (1980) Statistics at Square One. London, British Medical Assoc., pp. 1-60.

\author{
Guido M. P. J. Costongs and \\ Piet C. W. Janson \\ Afdeling Klinische Chemie \\ Maaslandziekenhuis \\ Walramstraat 23 \\ NL-6131 BK Sittard \\ The Netherlands
}

